\title{
AKTIVITAS ANTIOKSIDAN EKSTRAK METANOL PADA EKSTRAK VIRGIN MINYAK ZAITUN KEMASAN
}

\author{
MiRna Ulfa FAUZIAH $^{1}$, ASEP SUPRIADIN ${ }^{1 *}{ }^{*}$, DAN NILA T BERGHUIS ${ }^{1}$ \\ ${ }^{1}$ Jurusan Kimia, Fakultas Sains dan Teknologi, UIN Sunan Gunung Djati Bandung, \\ Jl. A. H. Nasution No. 105 Cibiru Kota Bandung \\ *alamat email korespondensi: asupriadin@uinsgd.ac.id
}

\begin{abstract}
Informasi Artikel
Riwayat Naskah :

Diterima pada 20

November 2017

Diterima setelah

direvisi pada 27

Desember 2017

Diterbitkan pada 29

Desember 2017

Kata Kunci: Ekstrak virgin minyak zaitun, DPPH; UVVis; FTIR; ${ }^{1} \mathrm{H}-\mathrm{NMR}$.

Keywords: extra virgin olive oil; $U L V$ Vis; DPPH; FTIR; ${ }^{1} H-N M R$.

Abstrak/Abstract

Ekstrak virgin minyak zaitun merupakan perasan pertama minyak zaitun yang banyak mengandung polifenol dan tokoferol yang berperan penting dalam aktivitas antioksidan. Penelitian ini bertujuan untuk mengetahui kandungan hasil ekstraksi ekstrak metanol pada ekstrak virgin minyak zaitun yang berasal dari buah zaitun Italy yang beredar dipasaran Indonesia serta untuk mengetahui aktivitas antioksidannya dengan menggunakan metode DPPH (1,1-difenil-2-pikrilhidrazil) yang diukur dengan spektrofotometer UV-Vis pada panjang gelombang $517 \mathrm{~nm}$ dengan vitamin $\mathrm{C}$ sebagai pembanding. Penggunaan sonikator dan sentrifugasi digunakan dalam proses pemisahan. Senyawa ekstrak metanol diidentifikasi dengan analisis FTIR dan ${ }^{1} \mathrm{H}-\mathrm{NMR}$. Perhitungan $\mathrm{IC}_{50}$ dilakukan dengan menggunakan persamaan regresi linier. Hasil penelitian ini menunjukkan ekstrak metanol pada ekstrak virgin minyak zaitun mengandung senyawa flavonoid dan turunan fenol yang memiliki nilai $\mathrm{IC}_{50}$ 474,901 ppm dengan vitamin C sebagai pembanding sebesar 5,9993 ppm.

Extra virgin olive oil is the first squeeze of olive oil that contains polyphenols and tocoferol are plays an important role in antioxidant activity. This research aims to determine the content of extraction of methanol extract on extra virgin olive oil derived from Italian olives circulating in the market of Indonesia and to know its antioxidant activity by using DPPH (1,1-difenil-2-fikrilhidrazin) method as measured by UV-Vis spectrophotometer at $517 \mathrm{~nm}$ wavelength with vitamin $C$ as comparison. The use of sonicator and sentrifugation is used in the separation process. The methanol extract compounds identified by FTIR and ${ }^{1} H$-NMR analysis. Calculating of $I C_{50}$ is done by using linear regression equation. The results of this study showed extract methanol extra virgin olive oil containing flavonoid compounds and phenol derivatives have IC 50474.901 ppm with vitamin C as a comparison of 5.9993 ppm.
\end{abstract}

\section{PENDAHULUAN}

Makanan merupakan kebutuhan primer bagi kehidupan manusia. Dalam setiap konsumsi makanan diperlukan keseimbangan gizi, adapun jika mengkonsumsi makanan yang mengandung banyak gula tidak dianjurkan oleh pakar kesehatan karena semakin banyak gula yang dikonsumsi, imunitas dalam tubuh manusia akan semakin berkurang dan resiko penyakit degeneratif seperti kanker payudara pun semakin tinggi.

Dalam hal ini ekstrak virgin minyak zaitun merupakan minyak zaitun perasan pertama memiliki banyak kandungan polifenol dan tokoferol yang berperan aktif dalam penghancuran sel kanker dan penyakit radang paru-paru. Distribusi penyebaran ekstrak virgin minyak zaitun sendiri sudah sangat banyak tersebar diseluruh dunia dari berbagai jenis buah zaitun seperti buah zaitun coratina yang merupakan khas dari Negara Italy [1].

Zaitun (Olea europea) telah dikenal sebagai pohon yang dapat hidup dan berbuah hingga 2000 tahun, memilki warna ungu muda hingga hitam ketika matang yang berupa (drupe) atau jenis buah yang bertekstur keras seperti batu. Dalam pembuatan minyak zaitun sendiri digunakan buah zaitun yang tidak terlalu matang karena semakin matang tingkat kandungan senyawa polifenol dan antioksidannya semakin sedikit. Dalam buah zaitun sendiri terkandung banyak senyawa penting bagi kehidupan manusia yang dapat menyembuhkan penyakit degeneratif seperti kanker dan radang paru-paru [2].

Senyawa-senyawa yang terdapat pada ekstrak virgin minyak zaitun dapat melindungi dari berbagai mekanisme reaksi. Seperti oksidasi protein, DNA dan lipid yang berkontribusi dalam perkembangan kanker, antioksidan pada ekstrak virgin minyak zaitun dapat menjadi alat kemoterapi. Penelitian pada ekstrak virgin minyak zaitun dan komponennya mengacu pada kapasitas untuk menghambat proses proliferase dan apoptosis beberapa sel tumor [2].

Antioksidan sendiri merupakan suatu zat yang dapat memperlambat, menunda dan bahkan 
mencegsh proses oksidasi dalam suatu sel hidup dan merupakan suatu zat yang bermanfaat untuk kesehatan serta berperan penting dalam menjaga mutu pangan [3]. Proses oksidasi pada sel hidup terjadi akibat gaya hidup dan pola makan yang tidak sehat seperti banyak mengkonsumsi daging yang dibakar dengan api langsung dan banyak mengkonsumsi gula yang bukan berasal dari buahbuahan.

Radikal bebas penyebab utama proses oksidasi merupakan suatu molekul atau atom yang memiliki satu atau lebih elektron yang tidak berpasangan. Elektron tersebut sangat reaktif dan cepat bereaksi dengan molekul lain sehingga terbentuk radikal bebas baru dalam jumlah yang besar dan terus menerus. Radikal bebas tersebut dapat menimbulkan kerusakan pada sel dan menyebabkan berbagai penyakit seperti tumor, kanker, ateroklerosis, katarak, keriput, penuaan dan lain sebagainya [4].

Antioksidan merupakan salah satu senyawa yang mampu menghambat penuaan dan mengatasi berbagai macam penyakit degeneratif yang diakibatkan oleh radikal bebas dan juga menghambat radikal bebas serta mencegah proses oksidasi pada suatu sel hidup. Penentuan aktivitas antioksidan dapat dilakukan salah satunya dengan menggunakan metode DPPH (1,1 difenil-2pikrilhidrazil). Metode ini digunakan karena bersifat sederhana, mudah, cepat dan peka serta hanya memerlukan beberapa sampel saja. Senyawa antioksidan akan bereaksi dengan radikal DPPH melalui mekanisme donasi atom hidrogen dan menyebabkan terjadinya peluruhan warna DPPH dari ungu ke kuning. $\mathrm{IC}_{50}$ (Inhibition Concentration $_{50}$ ) adalah konsentrasi efektif zat dalam sampel yang dapat menghambat $50 \%$ absorbansi DPPH. Semakin kecil nilai $\mathrm{IC}_{50}$ semakin kuat daya antioksidannya, harga $\mathrm{IC}_{50}$ berarti berbanding terbalik dengan kemampuan zat atau senyawa yang bersifat antioksidan [5].

Rasulullah SAW dalam hadits bersabda "Minumlah minyak zaitun dan berminyak dengannya karena sesungguhnya ia adalah dari pohon yang diberkahi" (HR Baihaqi dan Ibnu Majah) [6]. Minyak zaitun sangat dianjurkan oleh Nabi shalallahu'alaihi wasallam untuk digunakan diluar tubuh seperti menggosokkan ke daerah kulit baik daerah kulit tubuh maupun kulit kepala dan juga dianjurkan untuk diminum hal ini dimaksudkan untuk kesehatan tubuh atau sebagai obat berbagai penyakit, karena telah disebutkan bahwa minyak zaitun ini berasal dari pohon yang diberkahi. Berkah tersebut dapat berupa bermanfaat bagi manusia itu sendiri.

\section{EKSPERIMEN}

\section{Material}

Bahan-bahan yang digunakan untuk penelitian ini adalah ekstrak virgin minyak zaitun (p,Italy), metanol (Teknis), n-heksana (Teknis), pereaksi DPPH (Sigma aldrick, Jerman), etanol (Sigma Aldrick, Jerman), HCl pekat (Teknis), pita $\mathrm{Mg}, \mathrm{FeCl}_{3} 1 \%$ (Teknis), pereaksi bouchardat, $\mathrm{CuSO}_{4} .5 \mathrm{H}_{2} \mathrm{O}$ (Teknis), kalium natrium tartrat (Teknis), NaOH (Teknis), gragon drop (Teknis), Akuades.

\section{Instrumentasi}

Pengujian aktivitas antioksidan ekstrak virgin minyak zaitun digunakan Spektrofotometer Ultraviolet-Sinar Tampak merek Tecan dan pengujian senyawa hasil ekstraksi dengan Karakterisasi Fourier Transform InfraRed (FTIR) merek IR-Prestige 21 dan Nuclear magnetic resonance $\left({ }^{1} \mathrm{H}-\mathrm{NMR}\right)$ merek Magritek.

\section{Prosedur}

Pada penelitian yang dikhususkan pada kajian aktivitas antioksidan ekstrak metanol pada ekstrak virgin minyak zaitun kemasan, langkahlangkah yang dilakukan ialah sampling ekstrak virgin minyak zaitun dengan menggunakan 2 pelarut polar dan non polar kemudian diekstraksi, evaporasi serta sentrifugasi. Selanjutnya setelah mendapatkan ekstrak metanol kemudian dikarakterisasi dengan instrumen FTIR dan ${ }^{1} \mathrm{H}-$ NMR , kemudian di uji fitokimia dan antioksidan dengan menggunakan metode DPPH (1,1-difenil2-pikrilhidrazil).

\section{Sampling Ekstrak Virgin Minyak Zaitun}

Sampel ekstrak virgin minyak zaitun diukur dengan gelas ukur sebanyak $90 \mathrm{~mL}$ kemudian dicampurkan dengan $90 \mathrm{~mL} n$-heksana dan $150 \mathrm{~mL}$ metanol lalu dihomogenkan. Campuran sampel ekstrak virgin minyak zaitun dengan pelarut nheksana dan metanol tersebut untuk satu menit dihomogenkan kemudian campuran tersebut disonikasi dengan sonikator selama 5 menit dengan suhu $20^{\circ} \mathrm{C}$. Setelah terpisah terdapat 2 fasa yaitu fasa metanol dan fasa n-heksana. Ekstrak metanol disentrifugasi $3500 \mathrm{rpm}$ selama 10 menit. Sedangkan ekstrak n-heksana ditambahkan $150 \mathrm{~mL}$ $\mathrm{MeOH}$ dievaporasi $39^{\circ} \mathrm{C} 200$ mbar. Kemudian residu yang dihasilkan diekstraksi dengan $1 \mathrm{~mL}$ $\mathrm{MeOH}$ : Air. Lalu disonikasi selama 5 menit, setelah itu ditambahkan $5 \mathrm{~mL}$ n-heksana dalam 1 menit dicampurkan. Kemudian disentrifugasi 
selama 10 menit dengan kecepatan $13000 \mathrm{rpm}$. Bagian ekstrak metanol $(\mathrm{MeOH})$ yang dihasilkan dikarakterisasi dan diuji antioksidan dengan pereaksi DPPH.

\section{Penapisan Fitokimia}

\section{Uji flavonoid}

Ekstrak sampel sebanyak 1-2 mL ditambahkan $10 \mathrm{~mL}$ metanol dipanaskan kemudian disaring saat masih panas. Filtrat dipekatkan dalam water bath setelah itu ditambahkan 3 tetes asam klorida pekat dan logam $\mathrm{Mg}$.

\section{Uji fenol}

Ekstrak sampel $2 \mathrm{~mL}$ ditambahkan 3 tetes $\mathrm{FeCl}_{3} 1 \%$ hasil positif yang ditunjukkan ketika positif fenol adalah perubahan warna menjadi warna hijau atau merah.

\section{Uji alkaloid}

Ekstrak sampel $1 \mathrm{~mL}$ ditambahkan dengan 1-2 tetes pereaksi Bouchardat. Hasil menunjukkan positif ketika sampel menunjukkan adanya endapan. Untuk alkaloid amina dilakukan KLT pada ekstrak kemudian disemprotkan Dragon drop, menunjukkan positif amina ketika pada noda KLT terdapat pemisahan warna pada noda terlihat berwarna jingga.

\section{Uji aldehid}

Pembuatan pereaksi fehling $\mathrm{A}$ dan $\mathrm{B}$, pertama pembuatan fehling A $3,5 \mathrm{~g} \mathrm{CuSO}_{4} .5 \mathrm{H}_{2} \mathrm{O}$ dalam $50 \mathrm{~mL}$ aquadest menghasilkan fehling A. setelah itu pembuatan fehling B sebanyak 17,3 g kalium natrium tartrat ditambahkan $5 \mathrm{~g} \mathrm{NaOH}$ dalam air hingga $50 \mathrm{~mL}$ menghasilkan larutan fehling B. Ekstrak sampel sebanyak $2 \mathrm{~mL}$ ditambahkan fehling A dan B dengan perbandingan yang sama. Hasil positif pada uji aldehid dengan menggunakan fehling A dan B yaitu sampel berubah warna menjadi warna merah bata.

\section{Uji Aktivitas Antioksidan Metode DPPH}

Sampel ekstrak virgin minyak zaitun yang telah diekstraksi bagian fraksi metanol dipipet sebanyak 1,0 mL ke dalam labu ukur $5 \mathrm{~mL}$ ditanda bataskan dengan metanol. Kemudian didapatkan larutan ekstrak virgin minyak zaitun konsentrasi 4000 ppm. Dari larutan konsentrasi 4000 ppm dibuat larutan konsentrasi $100 \mathrm{ppm}$ dengan melakukan pengenceran pada labu ukur $10 \mathrm{~mL}$ dan ditanda bataskan dengan metanol. Dari larutan sampel konsentrasi $100 \mathrm{ppm}$ dibuat larutan dengan konsentrasi 0,10, 20, 30, 40, dan 50 ppm dengan cara pada Tabel 1. Pada tabel tersebut terdapat jumlah volume yang harus ditambahkan untuk sampel dan pelarut sedangkan volume DPPH sama yaitu $0,2 \mathrm{~mL}$. Pembuatan larutan DPPH dengan cara ditimbang $1,0 \mathrm{mg}$ DPPH kemudian dimasukkan kedalam labu ukur $10 \mathrm{~mL}$ ditanda bataskan dengan etanol. Dicampurkan dan disimpan selama 30 menit pada suhu ruang. Selanjutnya, diukur absorbansinya dengan Spektrofotometer UV-Vis pada panjang gelombang $517 \mathrm{~nm}$. Besarnya daya antioksidan dapat dihitung dengan dengan rumus :

$$
\% \text { Daya antioksidan }=\frac{\text { Absorban DPPH awal-Absorban DPPH akhir }}{\text { Absorban DPPH awal }} \times 100 \%
$$

Dari data antioksidan dibuat persamaan garis yang menandakan hubungan antara konsentrasi dengan (\%) daya antioksidan untuk menentukan daya antioksidan secara kuantitatif $\left(\mathrm{IC}_{50}\right)$.

Tabel 1. Variasi konsentrasi

\begin{tabular}{cccc}
\hline $\begin{array}{c}\text { Konsentrasi } \\
(\mathrm{ppm})\end{array}$ & $\begin{array}{c}\mathrm{MeOH} \\
(\mathrm{mL})\end{array}$ & $\begin{array}{c}\text { Sampel } \\
(\mathrm{mL})\end{array}$ & $\begin{array}{c}\mathrm{DPPH} \\
(\mathrm{mL})\end{array}$ \\
\hline 0 & 0,8 & 0 & 0,2 \\
10 & 0,7 & 0,1 & 0,2 \\
20 & 0,6 & 0,2 & 0,2 \\
30 & 0,5 & 0,3 & 0,2 \\
40 & 0,4 & 0,4 & 0,2 \\
50 & 0,3 & 0,5 & 0,2 \\
\hline
\end{tabular}

\section{HASIL DAN PEMBAHASAN}

\section{Hasil Penapisan Fitokimia}

Hasil penapisan fitokimia dari ekstrak metanol pada sampel ekstrak virgin minyak zaitun kemasan dapat dilihat pada Tabel 2.

Tabel 2. Hasil penafisan fitokimia.

\begin{tabular}{cc}
\hline Penapisan Fitokimia & Ekstrak Metanol \\
\hline Flavonoid & + \\
Alkaloid & - \\
Fenol & + \\
Aldehid & - \\
\hline
\end{tabular}


Berdasarkan hasil uji penapisan senyawa kimia diketahui bahwa ekstrak metanol ekstrak virgin minyak zaitun termasuk senyawa flavonoid dan fenol. Namun, ekstrak metanol tersebut menunjukkan hasil negatif pada uji alkaloid dan fehling A serta fehling B, penggunaan fehling A \& $\mathrm{B}$ digunakan untuk mengetahui adanya gugus aldehid pada larutan sampel adapun hasil positif alkaloid yaitu terbentuk endapan pada larutan setelah diteteskan pereaksi.

\section{Analisis Struktur Senyawa}

\section{Karakterisasi Fourier Transform InfraRed (FTIR)}

Untuk mengetahui gugus fungsi yang terdapat pada sampel, dilakukan pengukuran spektra FTIR yang dapat dilihat pada Gambar 1.

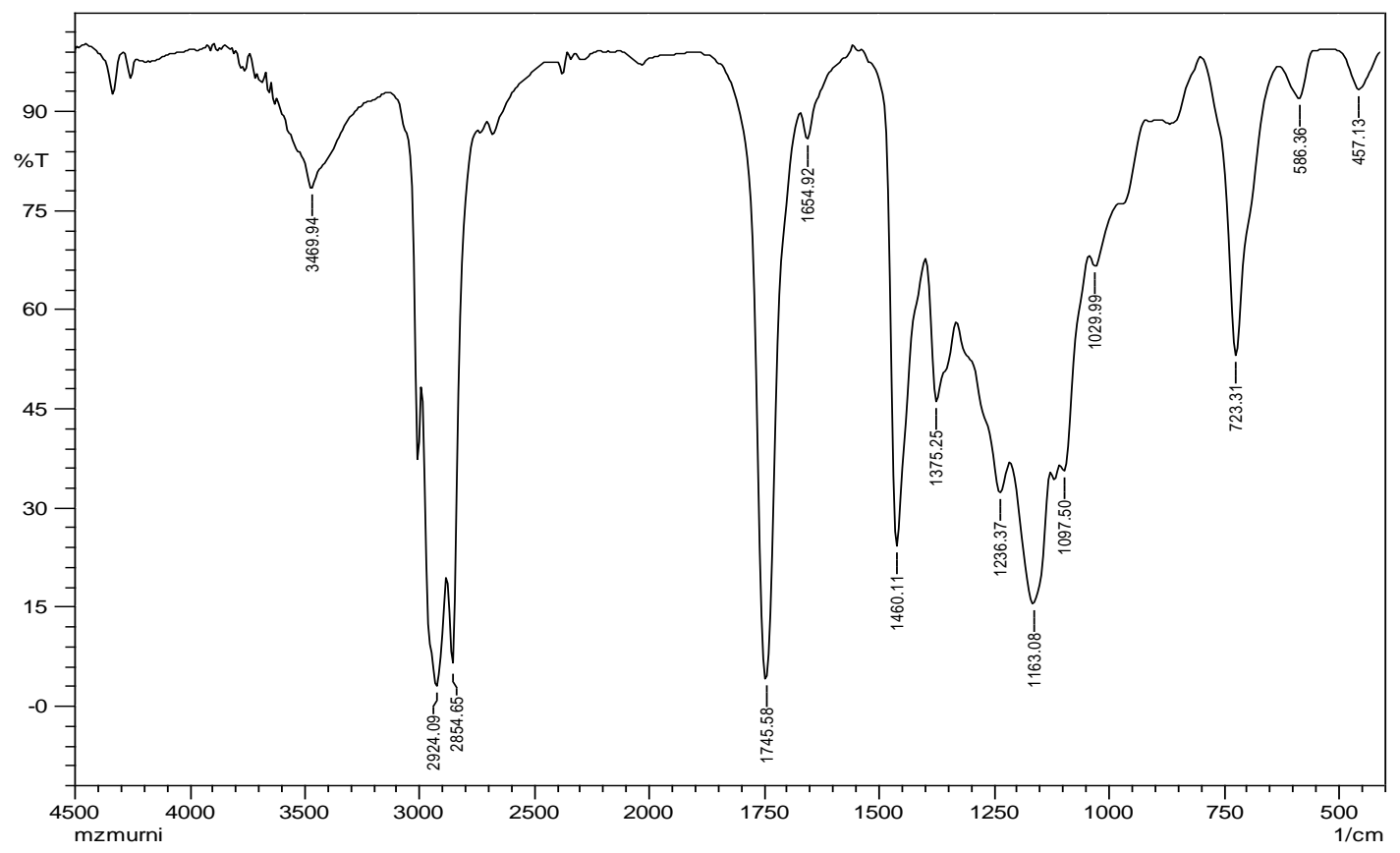

Gambar 1. Spektra FTIR ekstrak virgin minyak zaitun sebelum ekstraksi

Berdasarkan spektra FTIR tersebut adanya pola serapan sangat kuat $\mathrm{C}-\mathrm{H}$ alifatik jenuh disebabkan oleh vibrasi regang asimetri pada panjang gelombang 2924,09 $\mathrm{cm}^{-1}$. Pada panjang gelombang $2854,65 \mathrm{~cm}^{-1}$ terdapat pola serapan kuat diakibatkan vibrasi uluran C-H pada $\mathrm{CH}_{3}$ sedangkan pada panjang gelombang $1745,58 \mathrm{~cm}^{-1}$ terdapat pola serapan kuat akibat adanya vibrasi $\mathrm{C}=\mathrm{O}$ (keton alifatik). Pada panjang gelombang $1654,92 \mathrm{~cm}^{-1}$ terdapat vibrasi regang $\mathrm{C}=\mathrm{C}$ alifatik dengan pola serapan sedang hingga lemah. Adapun pada panjang gelombang $1460,11 \mathrm{~cm}^{-1}$ terdapat pola serapan sedang hingga kuat akibat adanya vibrasi $\mathrm{CH}_{2}$ sedangkan pada panjang gelombang $1375,25 \mathrm{~cm}^{-1}$ dengan pola serapan sedang hingga kuat diakibatkan adanya vibrasi tekukkan $\mathrm{O}-\mathrm{H}$. Pada panjang gelombang $1029,99 \mathrm{~cm}^{-1}$ dengan pola serapan sedang hingga kuat diakibatkan adanya vibrasi regang $\mathrm{C}-\mathrm{O}$ ester. Adapun interpretasi spektra FTIR ekstrak virgin minyak zaitun sebelum ekstraksi dapat dilihat pada Tabel 3.

Tabel 3. Interpretasi spektra FTIR ekstrak virgin minyak zaitun sebelum ekstraksi

\begin{tabular}{ccccc}
\hline $\begin{array}{c}\text { Bilangan } \\
\text { Gelombang }\left(\mathrm{cm}^{-1}\right)^{*}\end{array}$ & $\begin{array}{c}\text { Bilangan Gelombang } \\
\left(\mathrm{cm}^{-1}\right)^{* *}\end{array}$ & $\begin{array}{c}\text { Rentang } \\
\left(\mathrm{cm}^{-1}\right)\end{array}$ & $\begin{array}{c}\text { Intensitas } \\
\text { Referensi }\end{array}$ & Vibrasi Referensi \\
\hline 2924,09 & 2926 & $2940-2915$ & Kuat & Uluran C-H alifatik jenuh \\
2854,65 & 2864 & $2870-2850$ & Kuat & Uluran C-H pada $-\mathrm{CH}_{3}$ \\
1745,58 & 1718 & $1745-1715$ & Kuat & C=O (keton alifatik) \\
1654,92 & 1660 & $1665-1630$ & Sedang-Lemah & Vibrasi regang C=C alifatik \\
1460,11 & 1458 & $1480-1440$ & Sedang-Kuat & Guntingan CH $\mathrm{H}_{2}$ \\
1375.25 & 1377 & $1430-1370$ & Sedang-Kuat & Tekukan O-H \\
1029.99 & 1115 & $1100-1000$ & Sedang-Kuat & Vibrasi regang C-O \\
\hline
\end{tabular}

Keterangan: * Bilangan gelombang hasil

** Bilangan gelombang referensi 
Hasil interpretasi spektra FTIR dari hasil penelitian kemudian dibandingkan dengan spektra FTIR dari buku referensi elusidasi struktur senyawa organik yang ditulis oleh Unang Supratman [7]. Hasil perbandingan spektra FTIR sampel awal dengan hasil ekstraksi pada ekstrak metanol menunjukkan pola yang hampir sama hanya terdapat perbedaan bilangan gelombang yang tidak terlalu jauh. Perbandingan tersebut dapat dilihat pada masing-masing Gambar 1. dan
Pada ekstrak metanol ekstrak virgin minyak zaitun dilakukan pengukuran spektra FTIR yang dapat dilihat pada Gambar 2. Pada gambar tersebut terdapat interpretasi spektra FTIR ekstrak metanol ekstrak virgin minyak zaitun dapat dilihat pada Tabel 4. Tabel tersebut menunjukkan adanya panjang gelombang hasil sampel dan referensi untuk mengetahui gugus fungsi yang muncul pada spektra FTIR tersebut.

\section{Gambar 2.}

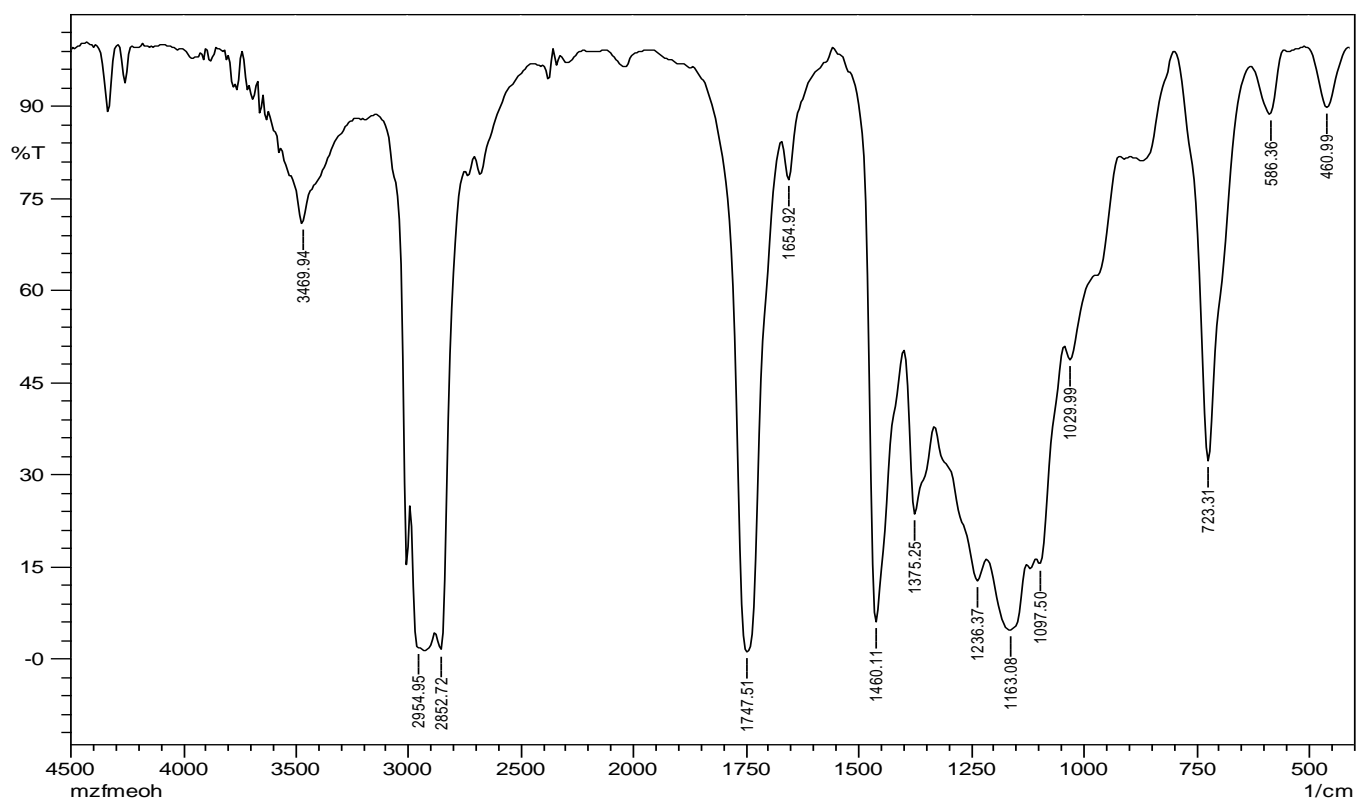

Gambar 2. Ilustrasi tiga dimensi mineral kristobalit.

Berdasarkan spektra FTIR ekstrak metanol ekstrak virgin minyak zaitun kemasan tersebut terdapat serapan yang kuat pada panjang gelomabang $2954,95 \mathrm{~cm}^{-1}$ yang disebabkan vibrasi uluran $\mathrm{C}-\mathrm{H}$ alifatik jenuh. Pada panjang gelombang $2852,72 \mathrm{~cm}^{-1}$ dengan serapan kuat menunjukkan adanya vibrasi uluran $\mathrm{C}-\mathrm{H}$ pada $\mathrm{CH}_{3}$ sedangkan pada panjang gelombang $1747,51 \mathrm{~cm}^{-1}$ merupakan akibat dari adanya vibrasi $\mathrm{C}=\mathrm{O}$ (keton alifatik) dengan serapan yang kuat. Terdapat serapan sedang sampai dengan lemah pada panjang gelombang $1654,92 \mathrm{~cm}^{-1}$ disebabkan vibrasi renggang $\mathrm{C}=\mathrm{C}$ alifatik. Pada panjang gelombang
$1460,11 \mathrm{~cm}^{-1}$ dengan serapan sedang hingga kuat diakibatkan adanya vibrasi gunting $\mathrm{CH}_{2}$ sedangkan pada panjang gelombang $1375,25 \mathrm{~cm}^{-1}$ dengan serapan sedang hingga kuat diakibatkan oleh adanya tekukkan O-H. Pada panjang gelombang $1090,97 \mathrm{~cm}^{-1}$ terdapat vibrasi regang $\mathrm{C}-\mathrm{O}$ ester dengan serapan sedang hingga kuat. Namun, dalam hal ini struktur kimia dari hasil ekstraksi pada ekstrak metanol ekstrak virgin minyak zaitun ini belum dapat ditentukan karena dibutuhkan pemisahan lebih lanjut.

Tabel 4. Interpretasi spektra FTIR ekstrak metanol ekstrak virgin minyak zaitun

\begin{tabular}{ccccc}
\hline $\begin{array}{c}\text { Bilangan } \\
\text { Gelombang }\left(\mathrm{cm}^{-1}\right)^{*}\end{array}$ & $\begin{array}{c}\text { Bilangan Gelombang } \\
\left(\mathrm{cm}^{-1}\right)^{* *}\end{array}$ & $\begin{array}{c}\text { Rentang } \\
\left(\mathrm{cm}^{-1}\right)\end{array}$ & $\begin{array}{c}\text { Intensitas } \\
\text { Referensi }\end{array}$ & Vibrasi Referensi \\
\hline 2954,95 & 2926 & $2940-2915$ & Kuat & Uluran C-H alifatik jenuh \\
2852,72 & 2864 & $2870-2850$ & Kuat & Uluran C-H pada $-\mathrm{CH}_{3}$ \\
1747,51 & 1718 & $1745-1715$ & Kuat & C=O (keton alifatik) \\
1654,92 & 1660 & $1665-1630$ & Sedang-Lemah & Vibrasi regang C=C alifatik \\
1460,11 & 1458 & $1480-1440$ & Sedang- Kuat & Guntingan CH $\mathrm{CH}_{2}$ \\
1375.25 & 1377 & $1430-1370$ & Sedang-Kuat & Tekukan O-H \\
1090.57 & 1115 & $1100-1000$ & Sedang-Kuat & Vibrasi regang C-O \\
\hline
\end{tabular}

Keterangan: * Bilangan gelombang hasil

** Bilangan gelombang referensi 
Berdasarkan spektra FTIR dari sampel awal dan hasil ekstraksi tersebut bahwa spektra tersebut hampir memiliki bentuk yang sama hanya bilangan gelombang yang tidak jauh berbeda. Pada spektra tersebut belum bisa menunjukkan struktur senyawa karena masih berupa ekstrak, perlu dilakukan pemisahan lebih lanjut untuk mengetahui struktur senyawa yang terdapat pada ekstrak metanol ekstrak virgin minyak zaitun tersebut.
Karakterisasi Nuclear magnetic resonance $\left({ }^{1} \mathrm{H}\right.$ NMR)

Adapun untuk mengetahui ikatan-ikatan pada ekstrak metanol ekstrak virgin minyak zaitun dilakukan pengukuran ${ }^{1} \mathrm{H}-\mathrm{NMR}$ yang dapat dilihat pada Gambar 3.

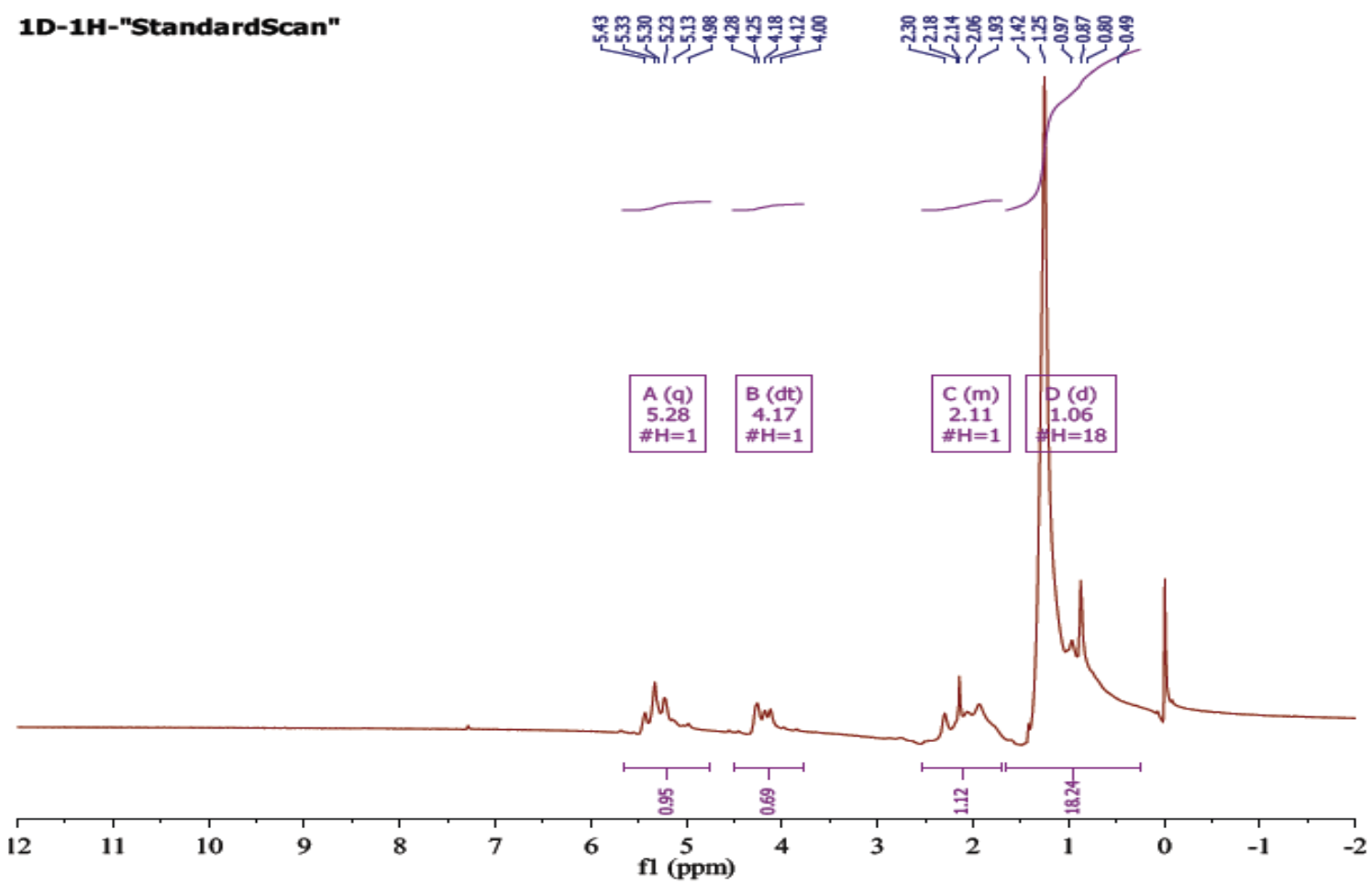

Gambar 3. ${ }^{1} \mathrm{H}-\mathrm{NMR}$ ekstrak metanol ekstrak virgin minyak zaitun.

Berdasarkan spektra ${ }^{1} \mathrm{H}-\mathrm{NMR}$ dilengkapi dengan integrator yang memberikan isyarat yang menunjukkan luas relatif di bawah peak-peak dalam spektrum tersebut. Integrasi yang muncul seperti deretan anak tangga yang digambarkan menumpuk dengan spektrum NMR. Tinggi anak tangga berbanding lurus dengan luas di bawah peak tersebut. Dari tinggi tersebut dapat ditentukan luar relatif di bawah peak-peak tersebut. Dalam kurva integrasi diukur dengan mistar dan dijumpai pada pergeseran 0,7-1,2 ppm sebesar $33 \mathrm{~mm}$ kemungkinan adanya pergeseran $\mathrm{CH}_{3}$ doublet karena memiliki satu tetangga dengan jumlah metil $\left(\mathrm{CH}_{3}\right)$ sebanyak $6 \mathrm{CH}_{3}$. Pada pergeseran 1,7-2,5 ppm diperkirakan adanya $\mathrm{CH}_{2}$ dan pada pergeseran di 4 ppm diperkirakan adanya $\mathrm{C}=\mathrm{C}$ alkena alifatik. Kemudian pada pergeseran 5-6 ppm diperkirakan adanya gugus $\mathrm{OH}$ yang merupakan $\mathrm{OH}$ triplet karena memiliki dua tetangga pada peak tersebut dan lebih jelasnya dapat dilihat pada Tabel 5.

Pada hasil ${ }^{1} \mathrm{H}-\mathrm{NMR}$ ekstrak metanol ekstrak virgin minyak zaitun tersebut diukur menggunakan pelarut kloroform dengan frekuensi magnet $43 \mathrm{~Hz}$. Harga $J$ merupakan tetapan penggabungan pada struktur senyawa tersebut. Namun belum dapat ditentukan struktur senyawa dari ekstrak metanol ekstrak virgin minyak zaitun tersebut karena diperlukan adanya pemisahan lebih lanjut.

Tabel 5. ${ }^{1} \mathrm{H}-\mathrm{NMR}(43 \mathrm{~Hz})$ ekstrak metanol

\begin{tabular}{cc}
\hline Posisi & ${ }^{\delta} \mathrm{H}$ \\
\hline 1 & $1,06(\mathrm{~d}, J=16.6 \mathrm{~Hz}, 18 \mathrm{H}$ \\
2 & $2,53-1.70(\mathrm{~m}, 1 \mathrm{H})$ \\
4 & $4,17(\mathrm{dt}, J=7.6,3.1 \mathrm{~Hz}, 1 \mathrm{H})$ \\
5 & $5,28(\mathrm{q}, J=4.3,1 \mathrm{H})$ \\
\hline
\end{tabular}

Hasil Uji Aktivitas Antioksidan Ekstrak Metanol Pada Ekstrak Virgin Minyak Zaitun Kemasan

Data absorbansi pengujian aktivitas antioksidan pada ekstrak metanol ekstrak virgin minyak zaitun dapat dilihat pada Tabel 6. dan data nilai $\mathrm{IC}_{50}$ pada pengulangan ke 1 dan ke 2 dapat dilihat pada Tabel 7. 
Tabel 6. Data pengujian aktivitas antioksidan minyak zaitun

\begin{tabular}{ccccc}
\hline \multirow{2}{*}{ Konsentrasi $(\mathrm{ppm})$} & \multicolumn{2}{c}{ Absorbansi } & \multicolumn{2}{c}{$\%$ Penghambatan } \\
\cline { 2 - 5 } & Pengulangan ke-1 & Pengulangan ke-2 & Pengulangan ke-1 & Pengulangan ke-2 \\
\hline 0 & 0.9067 & 0.9067 & 0.0000 & 0.0000 \\
10 & 0.8992 & 0.8984 & 0.8272 & 0.9154 \\
20 & 0.8935 & 0.8902 & 1.4558 & 1.8198 \\
30 & 0.8861 & 0.8826 & 2.2720 & 2.6580 \\
40 & 0.8757 & 0.8683 & 3.4190 & 4.2351 \\
50 & 0.8683 & 0.8398 & 4.2351 & 7.3784 \\
\hline
\end{tabular}

Tabel 7. Data aktivitas antioksidan (DPPH) minyak zaitun $\left(\mathrm{IC}_{50}\right)$

\begin{tabular}{cccc}
\hline \multirow{2}{*}{ Sample ID } & \multicolumn{3}{c}{$\mathrm{IC}_{50}(\mathrm{ppm})$} \\
\cline { 2 - 4 } & $\begin{array}{c}\text { Pengulangan } \\
\text { ke-1 }\end{array}$ & $\begin{array}{c}\text { Pengulang } \\
\text { an ke-2 }\end{array}$ & Rata-rata \\
\hline Minyak zaitun & 587,16 & 362,642 & 474,901 \\
\hline
\end{tabular}

Prinsip pengukuran pada metode DPPH yaitu secara kuantitatif dengan adanya perubahan intensitas warna ungu DPPH yang sebanding dengan konsentrasi larutan DPPH tersebut. perubahan intensitas warna tersebut terjadi karena radikal bebas yang dihasilkan diredam oleh reaksi yang terjadi yaitu bereaksinya molekul DPPH dengan atom hidrogen yang dilepaskan oleh molekul senyawa sampel sehingga terbentuk senyawa 2,2-diphenyl-1-picrylhydrazine dan menyebabkan terjadinya peluruhan warna DPPH dari ungu menjadi warna kuning dan akan mempengaruhi hasil serapannya pada spektrofotometer UV-Vis [8].

Perhitungan nilai $\mathrm{IC}_{50}$ dihasilkan dari nilai regresi absorbansi setiap variasi konsentrasi yang dilakukan, reaksi yang terjadi antara antioksidan dan DPPH dapat dilihat pada Gambar 4. Pada gambar tersebut menunjukkan bahwa DPPH yang memiliki elektron bebas bereaksi dengan senyawa antioksidan membentuk senyawa yang lebih stabil. DPPH sendiri memiliki warna ungu, ketika terjadi delokasi elektron oleh senyawa antioksidan DPPH berubah warna menjadi berwarna kuning muda. DPPH memiliki elektron bebas pada nitrogen dan ketika bereaksi dengan senyawa antioksidan nitrogen yang memiliki elektron bebas tersebut mengambil hidrogen pada senyawa antioksidan untuk berpasangan.

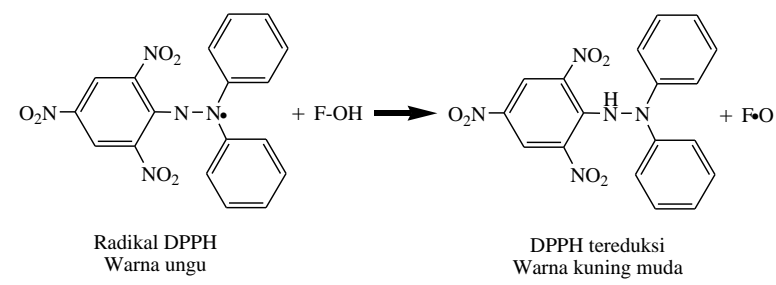

Gambar 4. Mekanisme peredaman radikal DPPH oleh antioksidan.
Pada struktur radikal DPPH akan terjadinya delokalisasi elektron yang menyebabkan larutan DPPH berwarna ungu, ketika pendonor elektron dicampurkan dengan larutan DPPH. Proses delokalisasi elektron akan terhenti dan DPPH akan tereduksi. Bentuk tereduksinya DPPH akan membuatnya kehilangan warna ungu dan berubah menjadi warna kuning. Adapun intensitas warna ungu pada DPPH berbanding lurus dengan konsentrasi DPPH. Penurunan intensitas warna yang terjadi diakibatkan oleh adanyanya penangkapan satu elektron oleh senyawa radikal DPPH dari zat antioksidan yang menyebabkan tidak adanya kesempatan elektron untuk beresonansi. Diagram hubungan konsentrasi dan \% penghambatan dapat dilihat pada Gambar 5. Adapun mekanisme reaksi antar vitamin $\mathrm{C}$ dengan DPPH dapat dilihat pada Gambar 6.

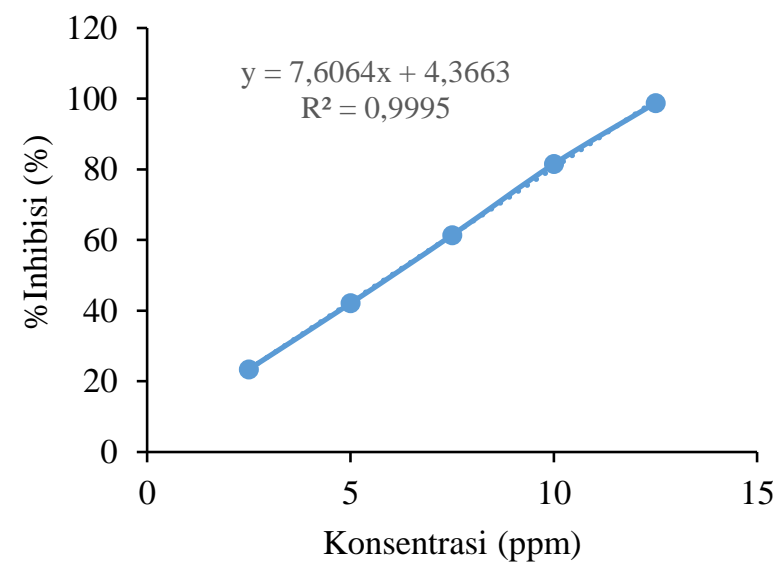

Gambar 5. Diagram kurva hubungan konsentrasi dan \% inhibisi vitamin

$\mathrm{IC}_{50}$ yang dimiliki oleh vitamin $\mathrm{C}$ sebesar 5,9993 ppm sedangkan ekstrak virgin minyak zaitun sebesar 474,901 ppm. Dalam hal ini, minyak zaitun berpotensi sebagai antioksidan dengan tingkatan sedang dibandingkan dengan vitamin $\mathrm{C}$. Vitamin $\mathrm{C}$ memiliki aktivitas antioksidan yang sangat tinggi dibandingkan dengan ekstrak virgin minyak zaitun. Akan tetapi ekstrak virgin minyak zaitun dipastikan memiliki aktivitas antioksidan yang potensial. 


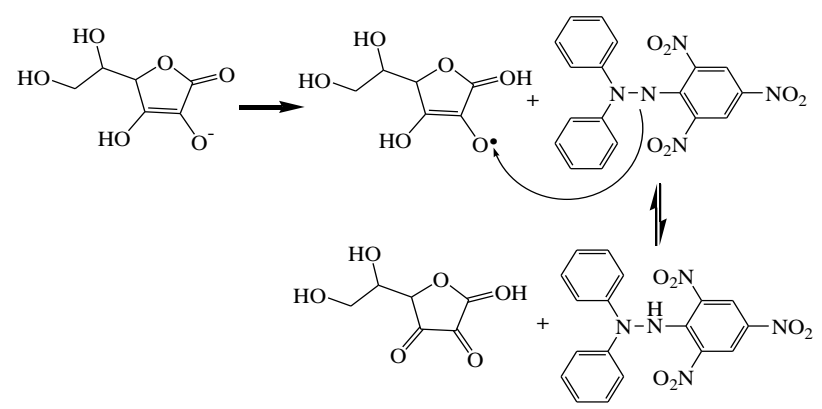

Gambar 6. Mekanisme Vitamin C Dengan DPPH [9].

Kemampuan sampel ekstrak virgin minyak zaitun dalam menangkap radikal bebas dalam hal ini DPPH merupakan suatu indikasi bahwa sampel tersebut beraktivitas antioksidan. Proses penangkapan radikal ini melalui mekanisme pengambilan atom hidrogen dari senyawa antioksidan oleh radikal bebas sehingga radikal bebas menangkap satu elektron dari senyawa antioksidan [10]. $\mathrm{IC}_{50}$ pada pengulangan ke 1 ini dihasilkan dari regresi linier sebesar 587,16 ppm.

\section{Pengulangan ke-1}

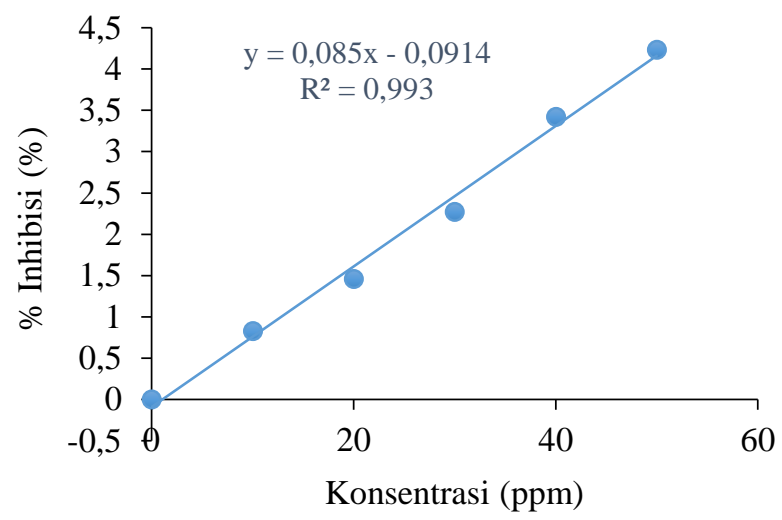

Gambar 7. Diagram aktivitas antioksidan (DPPH) ekstrak virgin minyak zaitun

Diagram pengulangan ke 2 dapat dilihat pada Gambar 8.

Pengulangan ke-2

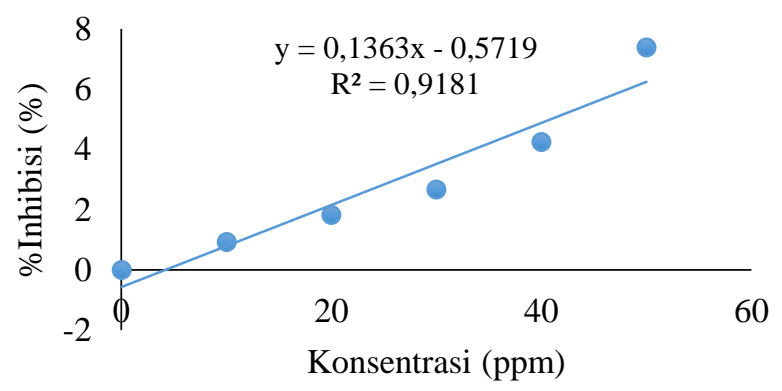

Gambar 8. Diagram aktivitas antioksidan (DPPH) ekstrak virgin minyak zaitun
Pada diagram Gambar 8. menunjukkan $\mathrm{IC}_{50}$ sebesar 362,642 ppm dari perhitungan nilai regresinya pada pengulangan kedua. Ekstrak virgin minyak zaitun berpotensi sebagai antioksidan. Dalam pemilihan pelarut yang digunakan untuk mengekstraksi ektrak virgin minyak zaitun dalam senyawa antioksidan sangat berpengaruh pada aktivitas antioksidan akibat dari perbedaan polaritas senyawa tersebut. Pada ekstraksi ekstrak virgin minyak zaitun ini digunakan pelarut polar yaitu metanol untuk mengambil senyawa yang penting dan memiliki aktivitas antioksidan. Sebagian besar senyawa penting tersebut bersifat polar.

\section{SIMPULAN}

Berdasarkan hasil yang diperoleh dari penelitian ini, dapat disimpulkan sebagai berikut:

1. Kandungan senyawa ekstrak metanol pada ekstrak virgin minyak zaitun adalah flavonoid dan senyawa turunan fenol berdasarkan uji penapisan fitokimia.

2. Aktivitas antioksidan ekstrak metanol pada ekstrak virgin minyak zaitun diketahui memiliki aktivitas yang potensial sebagai antioksidan dengan nilai $\mathrm{IC}_{50}$ sebesar 474,901 ppm.

\section{UCAPAN TERIMA KASIH}

Penulis mengucapkan terima kasih kepada Laboratorium Kimia ITB atas diskusi Fourier Transform Infra Red (FTIR) dan Laboratorium Sentral UNPAD atas diskusi Nuclear magnetic resonance $\left({ }^{1} \mathrm{H}-\mathrm{NMR}\right)$.

\section{REFERENSI}

[1] Wikipedia, "zaitun dan oleochantal," 20142015.

[2] International olive council, "Health Benefits of Olives and Olive Oil," 2012, pp. 6-7, 2012.

[3] Swasono R.Tamat, Thamrin Wikanta, and Lina S Maulina, "Aktivitas Antioksidan dan Toksisitas Senyawa Bioaktif dari," Jurnal Ilmu Kefarmasian Indonesia, vol. 5, pp. 3136, 2007.

[4] Herni Widyowati, Maria Ulfah, and Sumantri , "Uji Aktivitas Antioksidan Ekstrak Etanolik Herba Alfalfa (Medicago sativa L.) Dengan Metode DPPH (1,1 difenil-2-pikrilhidrazil)," pp. 25-32. 
[5] E Hanani, A Mun'im, and R Sekarini, "Identifikasi Senyawa Antioksidan dalam Spons Callyspongia SP dari Kepulauan Seribu," Majalah Ilmu Kefarmasian 2, vol. 3, p. 130, 2005.

[6] Said Hawwa, Ar-rasul shallallahua'laihi wa sallam, 1st ed., Suminarsih W, Ed. Jakarta: Gema Insani Press, 2006, vol. 536.

[7] Unang Supratman, Elusidasi Struktur Senyawa Organik. Bandung: Widya Padjadjaran, 2010.
[8] S.M. Khopkar, Konsep Kimia Dasar Analitik Terjemah A. Saptorahardjo. Jakarta: UIPress, 2003.

[9] J.B Harbone, Metode Fitokimia : Penuntun Cara Modern Menganalisa Tumbuhan. Bandung: ITB, 1987.

[10] Puteri Amelia, "Isolasi, Elusidasi Struktur dan Uji Aktivitas Antioksidan Senyawa Kimia dari Daun Garcinia benthami Pierre," Tesis, 2011. 